\title{
IIIIIII臨床開発と育薬17
}

創 薬

シリーズ(6)

\section{GPSP: 医薬品の製造販売後の調查及び試験の実施の基準}

要約 : GPSP は, 薬事法 14 条の 4 または 6 に基づく再 審査または再評価の申請に用いる製造販売後調査等の 実施基準であり，平成 16 年 12 月 20 日厚生労働省令 第 171 号「医薬品の製造販売後の調査及び試験の実施 の基準に関する省令」で規定されている，GPSP およ びその対象となる再審査制度および製造販売後調査等 について目的と内容を紹介するとともに今後のあり方 について考察した。

\section{はじめに}

GPSP は Good Post-Marketing Study Practice の略で あり，「医薬品の製造販売後の調査及び試験の実施の 基準に関する省令」(平成 16 年 12 月 20 日厚生労働省 令第 171 号）（以下，GPSP 省令）で規定された再審査 または再評価の申請資料の作成のために実施する製造 販売後の調査・試験の基準である.

薬事法（1）(以下，法）に基づく省令で規定された実 施基準は以下の 6 種がある。

【医薬品の製造販売承認の基準 (法 14 条関連)】

GMP: 医薬品及び医薬部外品の製造管理及び品質管 理の基準 (2)

GLP: 医薬品の安全性に関する非臨床試験の実施の 基準 (3)

GCP: 医薬品の臨床試験の実施の基準 (4)

GPSP: 医薬品の製造販売後の調査及び試験の実施の 基準 (5)

【医薬品製造販売業許可の基準（法 12 条関連）】

GQP: 医薬品, 医薬部外品, 化粧品及び医療機器の 品質管理の基準 (6)

GVP: 医薬品, 医薬部外品, 化粧品及び医療機器の製 造販売後安全管理の基準 (7)

再審査及び再評価は，法 14 条の 4 及び 6 に規定さ れた承認時に示された医薬品の安全性，有効性を再確 認する制度であり，GPSP はこれらの申請資料の基と
なる製造販売後の調査・試験（以下，製造販売後調査 等）の実施基準である。

再審査制度と製造販売後調査等を紹介した後, GPSP の目的と内容について紹介する.

\section{1. 再審査制度と GPSP について}

昭和 55 年に施行された改正薬事法により，再審査 制度，再評価制度，副作用報告制度が導入され，以降 30 年以上にわたり日本の医薬品の安全対策の 3 本柱 として運用されている。

新医薬品は，動物等を用いた基礎試験に引き続き， 患者等のヒトを対象とした臨床試験（治験）により有 効性ならびに安全性を厳格に確認・検証した成績に基 づき製造販売承認を申請し，厚生労働大臣により製造 販売の承認を受け医療の場に供される。

治験は有効性を正確に早期に把握するために，患者 と使用方法が限定されている（1)症例数が少ない，(2) 合併症・併用薬がない，(3)小览・高齢者を除外，(4)プ ロトコル通りの適用，(5)投与期間が短い).

一方，製造販売承認後の医薬品は，日常医療の使用 実態下において，多くの患者に対して，投与量・投与 方法・長期投与・併用薬等について多様な使われ方が なされる。その結果，予期しない副作用や重篤な副作 用の発現，承認の効能・効果，用法・用量に有効性が 認められないなどの事態が生じる.

再審査とは，製造販売承認から $4 \sim 10$ 年間の再審査 期間において, 新医薬品の使用実態における品質, 有 効性, 安全性を調査し, 再審査期間終了後 3 力月以内 にこれらの成績をまとめて申請し, 厚生労働大臣によ って再確認を受ける制度である（図 1)。

\section{1）再審査申請のために行う調査・試験}

法 14 条の 4 第 4 項において以下の規定がある.

「申請書にその医薬品又は医療機器の使用成績に関 する資料その他厚生労働省令で定める資料を添付しな

キーワード：GPSP，再審査，製造販売後調査

日本製薬工業協会 医薬品評価委員会 PMS 部会 副部会長（テ103-0023 東京都中央区日本橋本町 3-4-1 トリイ日本橋ビル）

E-mail: kumano.sb@om.asahi-kasei.co.jp＼cjkstart原稿受領日：2012 年 5 月 22 日，依頼原稿

Title: GPSP: Good Post-Marketing Study Practice. Author: Shinsaku Kumano 


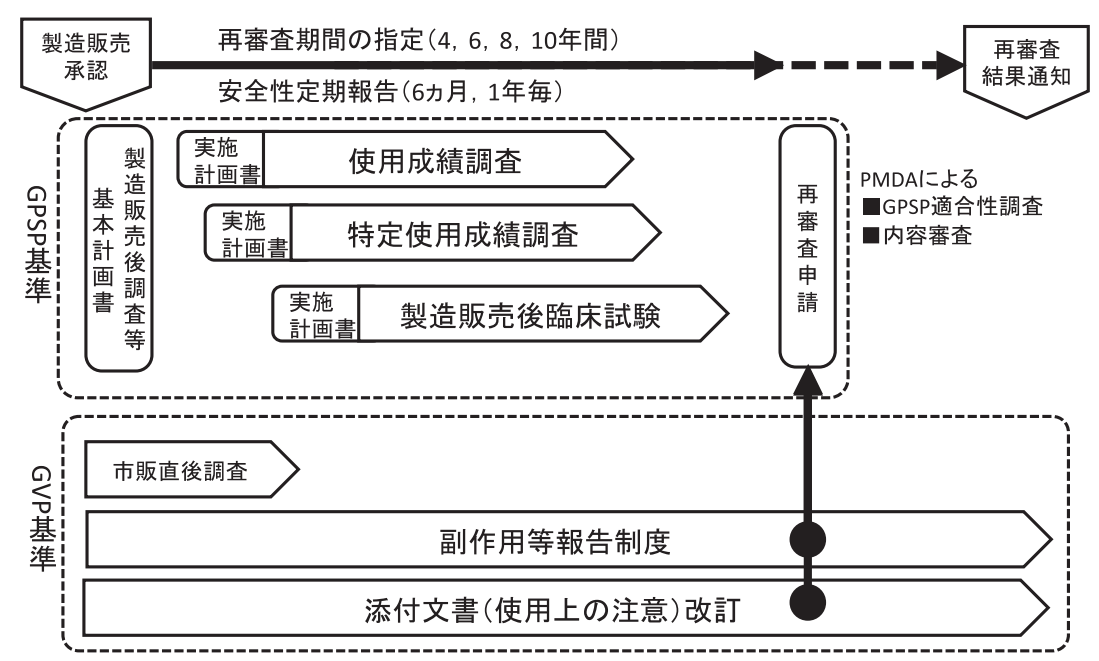

図 1 新医薬品の製造販売後の安全対策と再審査制度

ければならない，この場合において，当該申請に係る 医薬品又は医療機器が厚生労働省令で定める医薬品又 は医療機器であるときは, 当該資料は, 厚生労働大臣 の定める基準に従って収集され，かつ，作成されたも のでなければならない.」

「使用成績に関する資料」は, 製造販売後調查等に基 づき作成される。また，「厚生労働大臣の定める基準」 が GPSP である.

再審査申請のための製造販売後調査等は，再審査制 度発足当時は $0.01 \%$ て発現する副作用を把握するため 10,000 例を「使用成績調查」として実施することとさ れた，その後，製造販売後調查等に関するガイドライ ン（8）が示され, 現在では, 「使用成績調查」「特定使 用成績調査」「製造販売後臨床試験」に分類され医薬品 の特性, 目的に応じた調査・試験が実施されている.

\section{2）製造販売後調查等基本計画書}

再審査が指定された医薬品・医療機器 (以下, 新医 薬品等）は，販売開始予定時期の 1 力月前までに「製 造販売後調査等基本計画書」(以下, 基本計画書) を作 成し医薬品医療機器総合機構（以下, PMDA）に提出 する.この「基本計画書」には, その医薬品の開発時, 海外, 同類薬などの安全性に関する問題点を分析し,

再審査期間に実施する製造販売後調查等の概要を列挙 する.

さらに，個々の製造販売後調査等の実施に際しては， それぞれの「実施計画書」を策定し,「基本計画書」の 追加届として, 調查・試験の開始 1 力月前までに提出 し, PMDAの了承を受ける.

\section{3）安全性定期報告}

法 14 条の 4 第 6 項の規定「製造販売の承認を受け た者は, 厚生労働省令で定めるところにより, 当該医 薬品又は医療機器の使用の成績等に関する調查を行い,
その結果を厚生労働大臣に報告しなければならない.」 に基づき，一定期間毎（製造販売承認から 2 年間は 6 カ月毎，それ以降は 1 年間毎）に, 副作用等の発現状 況や実施した安全対策について調查単位期間の満了の 2 又は 3 カ月後までにPMDAに「安全性定期報告」と して報告しなければならない。「安全性定期報告」は, 再審査に基づく制度であると同時に，日・米・EU医 薬品規制調和国際会議 (ICH) の E2C ガイドラインと して合意された PSUR（定期的安全性最新報告）を日 本にStep5（各国の法規制に定めること）として導入 したものでもある(9).

\section{4）再審査申請}

再審查申請書㧍よび申請資料は施行規則 (10) で定 められており, 製造販売後調查等の成績, 副作用・感 染症報告一覧, 研究報告・海外措置報告, 使用上の注 意の改訂経緯等を記載し, 市販後の使用実態下での有 効性及び安全性について記載し厚生労働大臣に申請す る. 実際の申請は, PMDAに行う。

\section{5）再審查適合性調查}

再審査申請資料の信頼性を確保するために, PMDA 信頼性保証部に扔いて GPSP 適合性実地調査と書面調 查が行われる。

実地調査は, 申請企業が GPSP 省令に基づき, 社内 体制を有し製造販売後調査等管理責任者を設置してい るか, GPSP 業務手順書を策定しているかなど，主に 社内組織体制と業務手順について調查される。

書面調查は, 再審査資料に用いられた製造販売後調 查等の資料が，GPSP 手順に従って収集され，その結 果が申請資料に正しく反映されているかを原資料に遡 って確認される。具体的には，実施計画書が策定され ているか, 医療機関との調查契約書は正しいか, 調査 票の記載は正しいか, 調查結果の集計・解析は正しい 
か，その結果は申請資料に間違いなく記載されている かなどが調查される.

再審査適合性調査により適合と判断された後, 再審 査申請資料の科学的審査が行われる.すなわち, GPSP に不適合な事例が発見された場合, 該当する症 例あるいは調查施設を除外した再集計の実施，最悪の 場合には再審査申請の受理拒否も起こり得る.

\section{6）再審査の審査と結果通知}

PMDA の審査部門では, 信頼性保証部による適合性 調査で信頼性が確認された資料について, 有効性・安 全性の審査がなされる。審査結果は, 薬事・食品衛生 審議会に報告あるいは審議され，厚生労働大臣より法 14 条の 4 の規定に基づく結果が通知される。再審査 結果の通知は以下の 3 つに分かれる.

・カテゴリー 1 : 承認された効能・効果, 用法・用量 で有効性・安全性が認められる。

・カテゴリー 2 : 承認された効能・効果, 用法・用量 の一部を変更すれば有効性・安全性が認められる.

・カテゴリー 3 : 承認された効能・効果, 用法・用量 での有效性・安全性が認められない.

カテゴリー 2 の場合は, 再審査結果通知から 2 週間 以内に承認事項の一部変更を申請する。 また，カテゴ リー3 の場合は, 直ちに, 市場から当該医薬品を回収 する。

再審査は, 新薬承認と同じ法 14 条に属するが, すで に市販され企業に収益をもたらしている医薬品の存続 に関与する点が大きく異なる，再審査の審査と結果通 知の内容によっては当該企業にとって大きな痛手とな るばかりか, その医薬品で治療している医師や患者さ んにとっても多大な影響を及ぼすことになる。

この重要な再審査申請資料の信頼性を確保するため の基準として, GPSPが制定された。なお，再審査の ための市販後調査の実施基準は, 平成 3 年に GPMSP 「新医薬品等の再審査の申請のための市販後調査の実 施に関する基準」として制定されたが, 平成 17 年施行 の薬事法により，GVPとGPSPに分かれた，GVPにつ いては他稿で述べられるので, 以下 GPSP について述 ベる.

\section{GPSP 省令の内容}

GPSP は, 平成 16 年 12 月 20 日に厚生労働省令第 171 号として発令され平成 17 年 4 月 1 日より施行さ れた. GPSP は 12 条からなっている（表 1).

GPSP (5) は, 製薬企業における製造販売後調査等業 務の社内実施体制, 責任者及び業務手順書に対する基 準であると共に, 医療機関への製造販売後調査等の依 頼・契約の基準, さらには, 当局による再審査申請資 料の受入れの基準でもある. 製薬企業における日常の
表 1 GPSP 省令の構成

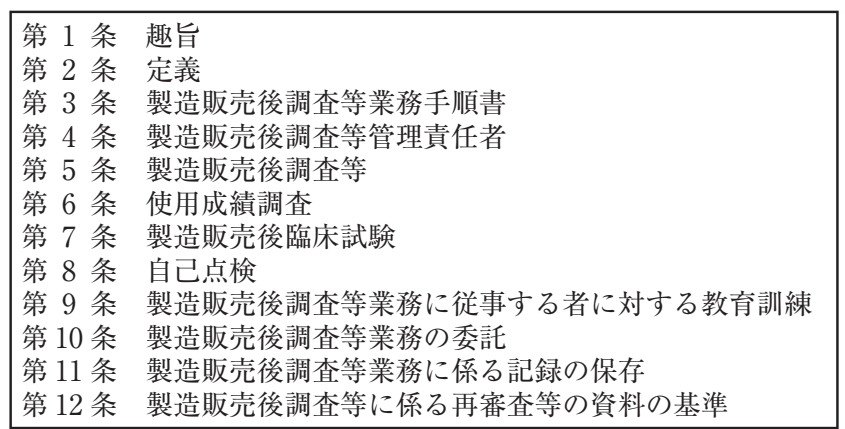

信頼性は，従事者の教育訓練，業務の自己点検等によ り確保されている.

\section{1）製造販売後調查等業務手順書の作成}

製造販売業者等は，製造販売後調查等を適正かつ円 滑に行うため, 製造販売後調查等業務手順書を作成し なければならない。

(1)使用成績調査に関する手順

(2)製販売後臨床試験に関する手順

(3)自己点検に関する手順

(4)製造販売後調査等業務に従事する者に対する教育訓 に関する手順

(5)製造販売後調査等業務の委託に関する手順

(6)製造販売後調查等業務に係る記録の保存に関する手 順

(7)その他製造販売後調査等を適正かつ円滑に実施する ために必要な手順

\section{2）製造販売後調査等の実施に係る組織体制}

製造販売業者等は，製造販売後調査等を統括するた めに製造販売後調査等管理責任者を置かなければなら ない．製造販売後調査等管理責任者は，販売に係る部 門（営業本部等）に属するものであってはならない. 製造販売業者等は，製造販売調查等管理責任者が述べ る意見を尊重するとともに，調査等の業務の遂行にあ たって支障が生じることがないように求められている.

\section{3）製造販売後調查等の種類}

製造販売後調査等とは, 製造販売業者が医薬品の品 質，有効性及び安全性に関する情報の収集，検出，確 認または検証のために行う使用成績調査，特定使用成 績調査又は製造販売後臨床試験を総じて称する，各調 查・試験は以下の通り定義される.

(1)使用成績調査 : 製造販売後調查等のうち, 診療にお いて，医薬品を使用する患者の条件を定めることな く, 副作用による疾病等の種類別の発現状況並びに 品質, 有効性及び安全性に関する情報の検出又は確 認を行う調査

(2)特定使用成績調査：使用成績調查のうち，製造販売 業者等が, 診療に扔いて, 小児, 高齢者, 妊産婦, 腎 
機能障害又は肝機能障害を有する患者, 医薬品を長 期に使用する患者その他医薬品を使用する条件が定 められた患者における副作用による疾病等の種類別 の発現状況並びに品質, 有効性及び安全性に関する 情報の検出又は確認を行う調査

(3)製造販売後臨床試験：治験若しくは使用成績調查の 成績に関する検討を行った結果得られた推定等を検 証し, 又は診療においては得られない品質, 有効性 及び安全性に関する情報を収集するため, 承認に係 る用法, 用量, 効能及び効果に従い行う試験

\section{4）製造販売後調査等の実施手順}

(1)使用成績調査（特定使用成績調査を含む）の手順

使用成績調査は，以下の内容に留意して実施する必 要がある。

・使用成績調査の目的を十分果たし得る医療機関に対 し，契約を文書により行い保存する。

・使用成績調査の医療機関との契約は電磁的方法によ っても可能である.

・使用成績調査実施計画書には, 調査の目的, 予定症 例数, 調査対象患者, 調査の方法や期間等を記載す る.

(2)製造販売後臨床試験の手順

再審査及び再評価に係る製造販売後臨床試験は, GPSP だけでなくGCPに従って実施する必要がある.

(3)その他の手順

製造販売後調査等に関する業務の自己点検, 業務に 従事する者の教育訓練, 業務の委託及び業務に係る記 録の保存について手順を定めなければならない.

\section{3. 今後の日本の安全対策と GPSP}

日本では，昭和 55 年に始まった再審査制度により， 新医薬品に対しては一定期間の安全性確認と安全対策 がなされてきた。

しかし近年, ICH が組織され, 平成 9 年の E2C ガイ ドラインによるPSURの導入 $(9)$, 平成 17 年の E $2 \mathrm{E}$ ガ イドラインによるファーマコビジランス計画の導入 （11）など医薬品の安全対策が世界的に協調されてき た。さらに, 欧州における医薬品リスク管理計画 (Risk Management Plan: RMP) の導入，米国における 副作用管理・軽減計画 (Risk Evaluation and Mitigation Strategy: REMS), Post-Marketing Requirment (PMR) の導入など，医薬品に関する安全性監視だけでなく, リスク分析とリスク最小化策による予測・予防型の安 全対策に移行してきている.

日本においても, 平成 22 年 4 月の「薬害肝炎事件の 検証及び再発防止のための医薬品行政のあり方検討 会」の最終提言 (12) を踏まえて厚生科学審議会医薬品 等制度改正検討部会が設置され，ここで検討した事項
をとりまとめて「薬事法等制度改正についてのとりま とめ」(13) が平成 24 年 1 月公表された。この中で, 市 販後安全対策の充実強化を目的に, 市販後調査の充実 と医薬品リスク管理制度の整備を行うべき等, 関連す る事項の検討を行うことが提言された。これにより, 平成 24 年 4 月に「医薬品リスク管理計画ガイダンス」 および「様式, 提出等の取り扱い] が通知され $(14,15)$, 平成 25 年 4 月以降本格施行される予定である.

この日本版 RMP は, 現行の製造販売後調査等基本 計画書, 安全性定期報告書, 再審査申請の再審査制度 を骨格としており，基本となる考え方は今までとほぼ 同じである. 今後も使用成績調査, 特定使用成績調査, 製造販売後臨床試験は安全性監視計画の大きな柱であ り, 実施に当たっては一層の科学性が求められる. そ の実施基準である GPSP は, RMPの要素も取り入れた 上で遵守が求められていくものである.

\section{文献}

1) 薬事法 (昭和 35 年 8 月 10 日 法律第 145 号) : http://law.e-gov.go.jp/htmldata/S35/S35HO145.html

2) 医薬品及び医薬部外品の製造管理及び品質管理の基準に関 する省令(平成 16 年 12 月 24 日厚生労働省令第 179 号)： http://law.e-gov.go.jp/htmldata/H16/H16F19001000179.html

3）医薬品の安全性に関する非臨床試験の実施の基準に関する 省令 (平成 9 年 3 月 26 日厚生省令第 21 号) : http://law.e-gov.go.jp/htmldata/H09/H09F03601000021.htm

4) 医薬品の臨床試験の実施の基準に関する省令 (平成 9 年 3 月 27 日厚生省令第 28 号) :

http://law.e-gov.go.jp/htmldata/H09/H09F03601000028.html

5) 医薬品の製造販売後の調査及び試験の実施の基準に関する 省令 (平成 16 年 12 月 20 日厚生労働省令第 171 号： http://law.e-gov.go.jp/htmldata/H16/H16F19001000171.html

6) 医薬品, 医薬部外品, 化粧品及び医療機器の品質管理の基準 に関する省令 (平成 16 年 9 月 22 日厚生労働省令第 136 号): http://law.e-gov.go.jp/htmldata/H16/H16F19001000136.html

7) 医薬品, 医薬部外品, 化粧品及び医療機器の製造販売後安全 管理の基準に関する省令 (平成 16 年 9 月 22 日厚生労働省令 第 135 号):

http://law.e-gov.go.jp/htmldata/H16/H16F19001000135.html

8) 平成 17 年 10 月 27 日付, 薬食審査発第 1027001 号「医療用医 薬品の製造販売後調査等の実施方法に関するガイドライン について」

9) 平成 9 年 3 月 27 日付, 薬安第 32 号「市販医薬品に関する定 期的安全性最新報告 (PSUR)について」

10) 平成 17 年 10 月 27 日付, 薬食審査発第 1027004 号「新医療用 医薬品の再審査申請に際し添付すべき資料について」

11) 平成 17 年 9 月 16 日付,薬食審査発第 0916001 号・薬食安発 第 0916001 号厚生労働省医薬食品局審査管理課長・安全対 策課長通知「医薬品安全性監視の計画について」

12) 薬害肝炎事件の検証及び再発防止のための医薬品行政のあ り方検討委員会「薬害再発防止のための医薬品行政等の見直 しについて (最終提言) 」(平成 22 年 4 月 28 日): http://www.mhlw.go.jp/shingi/2010/04/s0428-8.html (平成 24 年 2 月 10 日 access)

13) 厚生科学審議会医薬品等制度改正検討部会「薬事法等制度改 正についてのとりまとめ」(平成 24 年 1 月 24 日): http://www.mhlw.go.jp/stf/shingi/2r98520000020uxm.html (平成 24 年 2 月 10 日 access)

14) 平成 24 年 4 月 11 日付, 薬食安発 0411 第 1 号・薬食審査発 0411 第 2 号「医薬品リスク管理計画指針について」

15) 平成 24 年 4 月 26 日付, 薬食審査発 0426 第 2 号・薬食安発 0426 第 1 号「医薬品リスク管理計画の策定について」 